\title{
Emergence and extinction of Dipterocarpaceae in western India with reference to climate change: Fossil wood evidences
}

\author{
Anumeha Shukla*, R C Mehrotra and J S Guleria \\ Birbal Sahni Institute of Palaeobotany, 53 University road, Lucknow 226 007, India. \\ *Corresponding author.e-mail: anu_bsip@yahoo.co.in
}

Climate has played a crucial role in assigning a different kind of topography to Rajasthan and Gujarat since the Cenozoic time. Evidently, three genera, namely, Dipterocarpus Gaert. f., Hopea Roxb. and Shorea Roxb. of the Dipterocarpaceae are described from the Neogene sediments of western India (Rajasthan and Gujarat). These taxa are marked by their complete absence in the region today. The presence of Dipterocarpaceae in western India has been noticed from the Early Eocene up to the PlioPleistocene in deep time. The family is usually a dominant component of the humid tropical and subtropical flora of the Indo-Malayan region and its discovery, along with earlier described fossils from western India indicates existence of ancient tropical rain forests in western India. A change in the climate affected warm and humid conditions occurring there during the Cenozoic resulting in arid to semi-arid climate at present which is responsible for the ultimate extinction of Dipterocarpaceae in the region. In addition, the palaeobiogeography of Dipterocarpaceae is reviewed.

\section{Introduction}

Dipterocarpaceae, a well known family of the Asian rain forests (Ashton 1982, 1988), has been variously assigned to Malvales and Theales and consists of the following three subfamilies with an intercontinental disjunct distribution: (1) Dipterocarpoideae in the Asian tropics and Seychelles, (2) Pakaraimoideae in Guyana and Venezuela of South America and (3) Monotoideae in African tropics, Madagascar and southeast Colombia of South America (Maguire and Ashton 1977; Ashton 1982, 2003; Maury-Lechon and Curtet 1998). There are approximately 520 species belonging to 17 genera amongst which the Asian dipterocarps include 470 species alone. It constitutes prominent elements of the lowland rain forests (Aiba and Kitayama 1999) and is also well represented in the understorey. In south Asia, the dipterocarps are mainly distributed in tropical peninsula from Karnataka coast to the tip of southern India and northeast India (figure 1). Shorea robusta Roth (locally known as sal), commercially the most important timber of India, is a large deciduous tree occurring widely in northern and central India. In the northern or sub-Himalayan region, it has western limit in east Punjab and then extends eastwards through Uttar Pradesh, Bihar, Nepal, West Bengal, Bangladesh and Assam (Ghosh 1958). Asian dipterocarps deeply imprint the forest ecology and economy of the places where they grow.

The family Dipterocarpaceae was reported from the Palaeogene and Neogene sediments of India (Guleria 1992b; Srivastava and Mehrotra 2010), including the westernmost part (Lakhanpal et al. 1984; Dutta et al. 2009, 2011a, b; Rust et al. 2010;

Keywords. Origin; western India; Diptercarpus; Shorea; Hopea; palaeoclimate; phytogeography. 


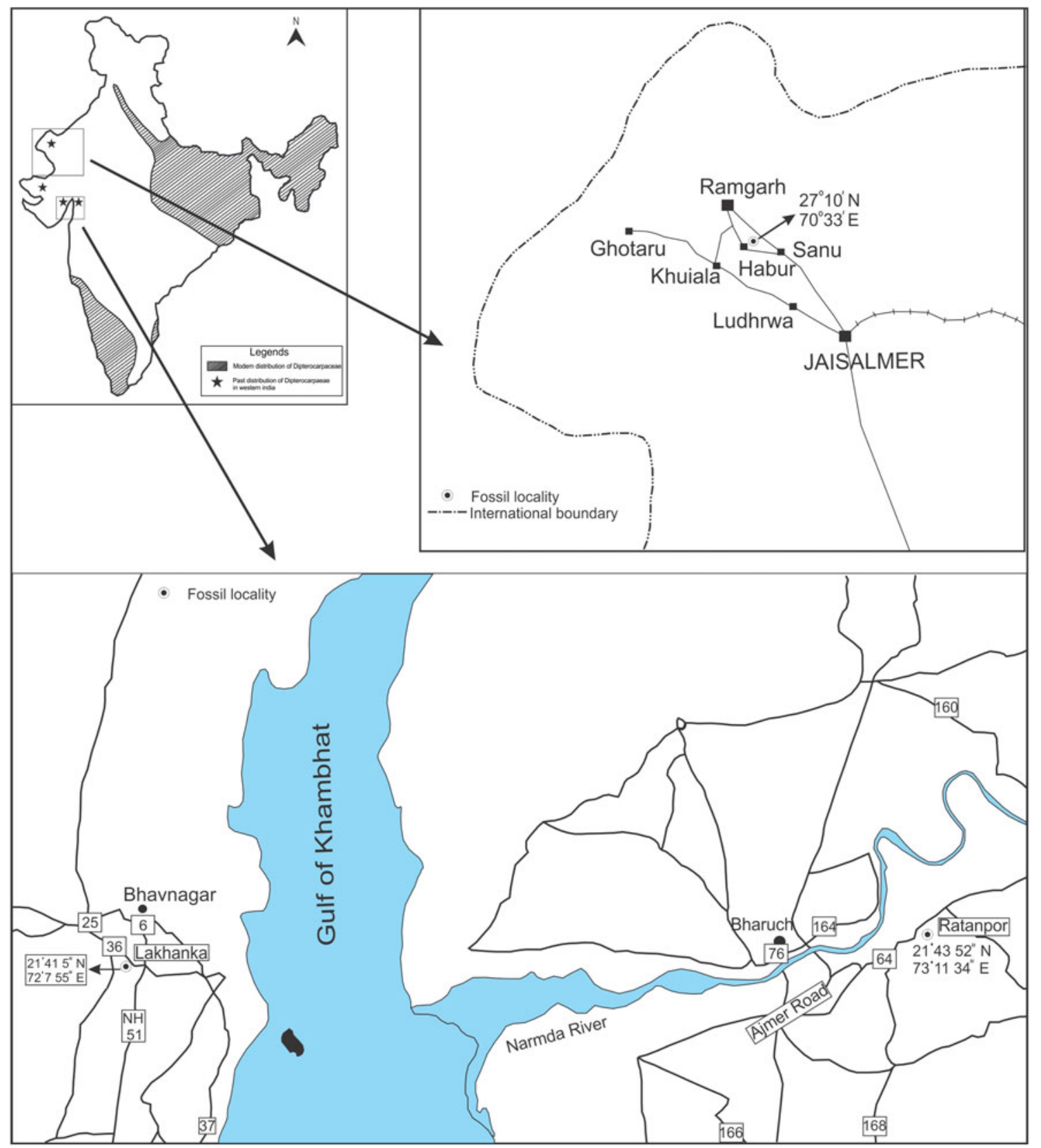

Figure 1. Map showing fossiliferous localities of Rajasthan and Gujarat. (Inset: map of India showing present (shaded area) and past (marked by stars) distribution of Dipterocarpaceae.)

Shukla et al. 2012). Apart from India, dipterocarpaceous remains were also reported from the Cenozoic of northeast and east Africa as well as south and southeast Asia. The fossil records are mainly represented by woods (Bancroft 1935; Ramanujam 1956; Schweitzer 1958; Navale 1962; Prakash 1965a, b; Lakhanpal 1970; Lemoigne 1978; Awasthi and Mehrotra 1993: Prasad 1993; Prakash et al. 1994; Guleria 1996; Tiwari and Mehrotra 2000; Mehrotra and Bhattacharyya 2002; Wang et al. 2006; Rust et al. 2010), leaves
(Lakhanpal and Guleria 1987; Prasad 1990, 1994; Antal and Prasad 1996), pollen grains (Muller 1981; Songtham et al. 2005; Rugmai et al. 2008; Dutta et al. 2011a, b) and fruit wings (Khan and Bera 2010; Shi and Li 2010; Shukla et al. 2012). The earliest confirmed fossil dipterocarp so far reported from SE Asia was from the Oligocene (34-23 Ma) sediments of Borneo (Muller 1981) which is also a centre of diversity of extant dipterocarps with more than 280 species (Ashton 1982, 1988). In the last decade, dipterocarpaceous pollen grains 
have been recorded from the Early Eocene sediments of western India (Acharya 2000; Dutta et al. 2011a, b).

The presence of Dipterocarpaceae in the Early Eocene to Plio-Pleistocene sediments of western India and its complete absence today in the region is a sign of drastic change in the climate which might be responsible for the complete extinction of the family from the region. The family may perhaps hold the distinction of being the most well known trees in the tropics and consequently the origin and antiquity of it is always a matter of concern.

\subsection{Regional geology}

The fossils collected for the present study from Rajasthan belong to the Shumar Formation of the Jaisalmer Basin. The formation is best exposed in Shumarwali Talai area and has a thickness of about $9.5 \mathrm{~m}$ in the type section (Narayanan et al. 1961). The surface and sub-surface geology indicates that the Shumar Formation comprises a sequence of alternating variegated clays, sandstone and glauconitic clay at the base followed by sandstone and variegated clays, limestone and calcareous sandstone and loose sandstone at the top (Guleria and Shukla 2011). In the outcrop, the formation is mainly composed of conglomerate with streaks of sandstone and silty clays (Dasgupta 1975). Singh (1982) opined that the sediments of this formation are not typical Sub-recent or Recent type such as alluvium, terraces, calcrete boulder beds, etc., and therefore, it may be logical to tentatively assign Pleistocene to Sub-recent age to this formation (Singh 2007, p. 152). The plant assemblage being described here is almost similar to the one recovered from the Mar Formation

\begin{tabular}{|c|c|c|c|c|c|c|}
\hline \multicolumn{3}{|c|}{ Stratigraphy } & \multicolumn{2}{|c|}{ Cambay Basin } & \multicolumn{2}{|c|}{ Saurashtra Basin } \\
\hline Era & Period & Age & Formation & Lithology & Formation & Lithology \\
\hline \multirow[b]{3}{*}{$\cup$} & \multirow{2}{*}{ 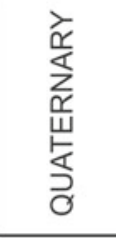 } & HOLOCENE & $\begin{array}{l}\text { Gujarat } \\
\text { alluvium }\end{array}$ & \multirow[t]{2}{*}{$\begin{array}{l}\text { Sand, silt, clays with } \\
\text { gravel beds }\end{array}$} & & $\begin{array}{l}\text { Alluvium, soils, } \\
\text { coastal deposits }\end{array}$ \\
\hline & & \multirow{2}{*}{ 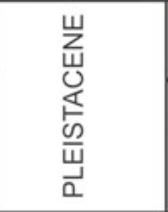 } & $\begin{array}{l}\text { Narmada } \\
\text { Formation }\end{array}$ & & $\begin{array}{l}\text { Chaya } \\
\text { Formation }\end{array}$ & $\begin{array}{l}\text { Shelly beach } \\
\text { rocks }\end{array}$ \\
\hline & \multirow{4}{*}{$\begin{array}{l}> \\
\propto \\
\varangle\end{array}$} & & $\begin{array}{l}\text { Jambusar } \\
\text { Fm. (not exposed) }\end{array}$ & $\begin{array}{l}\text { Coarse sand, } \\
\text { clays, calcrete }\end{array}$ & $\begin{array}{l}\text { Lakhanka } \\
\text { Fm. }\end{array}$ & $\begin{array}{l}\text { Agate conglomerate, } \\
\text { sandstone } \\
\text { coastal \& inland } \\
\text { miliolites }\end{array}$ \\
\hline \multirow[t]{3}{*}{$N$} & & \multirow{2}{*}{ PLIOCENE } & $\begin{array}{l}\text { Broach Fm } \\
\text { (not exposed) }\end{array}$ & $\begin{array}{l}\text { Claystone, } \\
\text { sandstone }\end{array}$ & \multirow{3}{*}{$\begin{array}{l}\text { Dwarka } \\
\text { Fm. }\end{array}$} & \multirow{3}{*}{$\begin{array}{l}\text { Silty clays, marls, } \\
\text { sandy limestone, } \\
\text { grit, sandy clays, sst, } \\
\text { fossil conglomerate }\end{array}$} \\
\hline & & & $\begin{array}{l}\text { Jhagadia } \\
\text { Formation }\end{array}$ & $\begin{array}{l}\text { Conglomerate, } \\
\text { sandstone }\end{array}$ & & \\
\hline & & \multirow{4}{*}{ MIOCENE } & ${ }^{\star}$ Kand Formation & $\begin{array}{l}\text { Conglomerate fossils, } \\
\text { limestone,clac. sst }\end{array}$ & & \\
\hline \multirow{2}{*}{ ш } & $\bar{\vdash}$ & & & & \begin{tabular}{|l|} 
Kuda Sandstone \\
Member
\end{tabular} & \multirow{3}{*}{$\begin{array}{l}\text { Fossil, gypseous, } \\
\text { clays limestone, } \\
\text { grit }\end{array}$} \\
\hline & $\propto$ & & $\begin{array}{l}\text { Babaguru } \\
\text { Formation }\end{array}$ & $\begin{array}{l}\text { Conglomerate, } \\
\text { sandstone }\end{array}$ & \begin{tabular}{l|l|} 
Gaj & $\begin{array}{c}\text { Bhumbli Conglo- } \\
\text { Fm. }\end{array}$ \\
merate Member \\
\end{tabular} & \\
\hline \multirow[t]{5}{*}{0} & $\begin{array}{l}\text { Ш } \\
\vdash\end{array}$ & & & & $\begin{array}{l}\begin{array}{l}\text { Ratanpur Clay } \\
\text { Member }\end{array} \\
\text {............. }\end{array}$ & \\
\hline & & OLIGOCENE & $?$ & $? \quad ?$ & & \\
\hline & & \multirow{2}{*}{ EOCENE } & Dinod Formation & $\begin{array}{l}\text { Fossil limestone } \\
\text { marl }\end{array}$ & & \\
\hline & & & $\begin{array}{l}\text { Vagadkhol } \\
\text { Formation }\end{array}$ & $\begin{array}{l}\text { Conglomerate grit, } \\
\text { sandstone clay } \\
\text { siltstone }\end{array}$ & & \\
\hline & & PALAEOCENE & & $\begin{array}{l}\text { Bauxite, } \\
\text { bentonite }\end{array}$ & & $\begin{array}{l}\text { Bauxite, } \\
\text { bentonite }\end{array}$ \\
\hline
\end{tabular}

Figure 2. Generalized stratigraphic chart of the Cenozoic basins of Gujarat (after Merh 1995) (fossilifereous horizons marked by stars). 

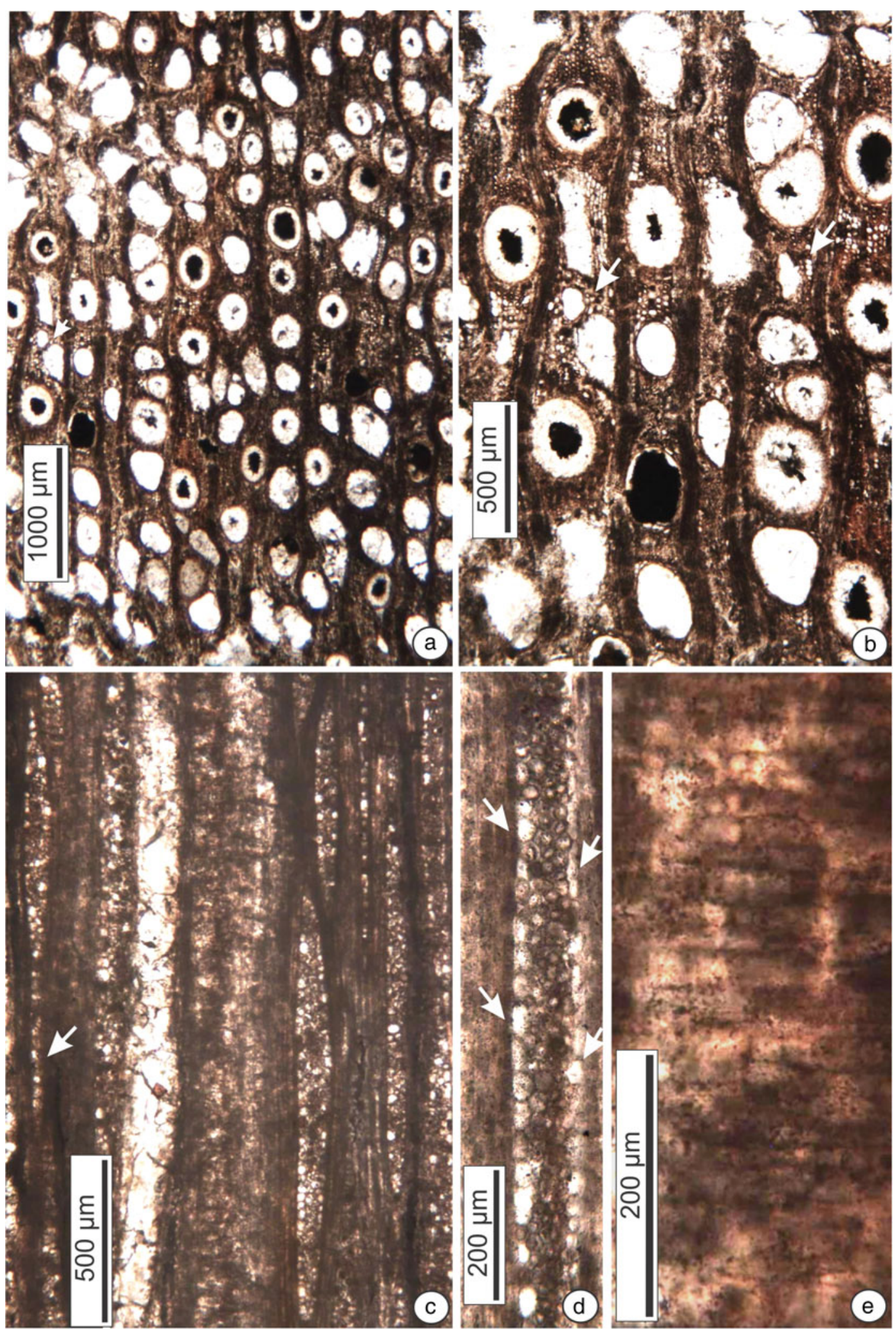

Figure 3. Dipterocarpoxylon jammuense Guleria and Srivastava (a), (b) transverse sections (T.S.) of the fossil showing exclusively solitary vessels and scattered gum canals (marked by arrow), (c) tangential longitudinal section (T.L.S.) of the fossil showing multiseriate rays with long tails (marked by arrow), (d) T.L.S. showing sheath cells on the flanks of a multiseraite ray (marked by arrows) and (e) radial longitudinal section (R.L.S.) showing heterogeneous ray tissue. 
of Bikanar and Kankawati Series (Pliocene) of Kachchh (Guleria 1983, 1984a, b, 1990, 1992a, 1996). As the age of Kankawati Series is considered to be Pliocene (Biswas 1965, 1971; Biswas and Deshpande 1970), the age of this formation could be equivalent to the Kankawati Series. Sedimentological and palaeontological studies are needed for more precise correlation and dating of this formation.

From Gujarat, the fossil woods were collected from two different horizons of Bharuch and Bhavnagar districts. From Bharuch, they were collected from Kand Formation which overlies the Babaguru Formation with an unconformity (figure 2) and constituted by calcareous sandstone with occasional conglomerate, clays, marl and thin fossiliferous limestone bands. A Lower Miocene (Burdigalian) age has been assigned to this formation (Merh 1995). A few fossil woods were also collected from Bhumbli Conglomerate of Gaj Formation in Bhavnagar, Gujarat. This formation is unconformably overlying the Deccan Traps and Lateritic rocks of the basin. The highly fossiliferous rocks of the Gaj Formation (Early to Middle Miocene) have been found exposed all along the coastal tracts from Bhavnagar to Okha Rann (Pandey et al. 2008). Fedden (1884) mapped these as 'Gaj Beds' and assigned an Upper Miocene age. The Gaj rocks have a characteristic earthy yellow appearance, contrasting with red and brown coloured landscape, wherever they overlie the lateritic rocks. Srivastava (1963) divided the Gaj Formation into three members - the lower Ratanpur Clay Member, the Bhumbli Conglomerate and the topmost Kuda Sandstone Member (figure 2). The Bhumbli Conglomerate Member is made up of fossiliferous conglomerate, grit and argillaceous sandstone with minor content of clay layers. Some plant fossils were recorded from this formation (Merh 1995). On the basis of microfossils and foraminifers, a Miocene age has been assigned to this formation (Merh 1995).

\section{Materials and methods}

Materials for the study came from the Neogene sediments of western India, including Rajasthan and Gujarat. From Rajasthan, a large number of silicified woods were collected from the Khuiala Limestone ridge situated $3-5 \mathrm{~km}$ west of the Habur Village (lat. $27^{\circ} 10^{\prime} \mathrm{N}$, long. $70^{\circ} 33^{\prime} \mathrm{E}$ ), which is about $57 \mathrm{~km}$ north of Jaisalmer (figure 1). Form Gujarat, a few fossil woods were collected from Lakhanka $\left(21^{\circ} 41^{\prime} 5^{\prime \prime} \mathrm{N}\right.$ : $\left.72^{\circ} 7^{\prime} 55^{\prime \prime} \mathrm{E}\right)$ to Mithi-Viri road, about $1-2 \mathrm{~km}$ before Mithi-Viri (figure 1). These woods were found embedded in soft sandstone layers. A few fossil woods were also collected from Ratanpurni River bed, Ratanpor $\left(21^{\circ} 43^{\prime} 52^{\prime \prime} \mathrm{N}\right.$ : $\left.73^{\circ} 11^{\prime} 34^{\prime \prime} \mathrm{E}\right)$ lying between Rajpardi and Jhagadia villages of the Bharuch District (figure 1).

For the study of xylotomical characters, thinsections of the fossil woods were prepared by standard lapidary techniques. Sections were cut in three planes, i.e., transverse, tangential longitudinal and radial longitudinal. Each face was polished and mounted onto a glass slide and surfaces were ground and polished with carborundum powder to a thickness of $30-40 \mu \mathrm{m}$. These sections were studied using high-power microscope and photographed with an attached DFC 290 digital camera. Identifications were made by comparing the anatomical characters with modern wood slides available at the Birbal Sahni Institute of Palaeobotany (BSIP), Lucknow and the Forest Research Institute, Dehradun. Descriptions follow the terminology of the IAWA Committee (1989). The type slides are housed in the museum of the Birbal Sahni Institute of Palaeobotany, Lucknow.

\section{Systematic description}

Family: Dipterocarpaceae

Genus: Dipterocarpoxylon Holden emend. Den Berger (1927)

Dipterocarpoxylon jammuense Guleria and Srivastava (2001)

Description: Wood diffuse-porous. Growth rings not seen. Vessels almost solitary, rarely in pairs, medium to large (figure 3a, b), evenly distributed 3-7 per $\mathrm{mm}^{2}$, circular to oval in shape, filled with tyloses or black colour content (figure 3b), t.d. $147-270 \mu \mathrm{m}$ and r.d. $215-349 \mu \mathrm{m}$, vessel elements $140-600 \mu \mathrm{m}$ long with truncate or oblique end walls; perforations simple; intervessel pits poorly preserved, alternate. Vasicentric tracheids present intermingled with parenchymatous cells forming thin sheath around the vessels. Axial parenchyma apotracheal and paratracheal, paratracheal parenchyma vasicentric, 1-3 cells wide (figure 3b), rarely short extensions joining adjacent vessels, apotracheal parenchyma scanty, only few diffuse cells present, occasionally in short tangential bands enclosing vertical gum canals (figure 3b); cells thin walled, 56-105 $\mu \mathrm{m}$ long and 19-22 $\mu \mathrm{m}$ wide. Rays 1-7 (mostly 3-6) seriate (figure 3c, d), homocellular to heterocellular (figure 3e), uniseriate rays $2-11$ cells or $180-750 \mu \mathrm{m}$ high, made up of upright cells only or both upright and procumbent cells, multiseriate rays made up of procumbent cells in the centre with uniseriate extensions of 2-10 upright cells at one or both

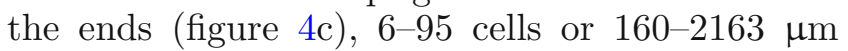



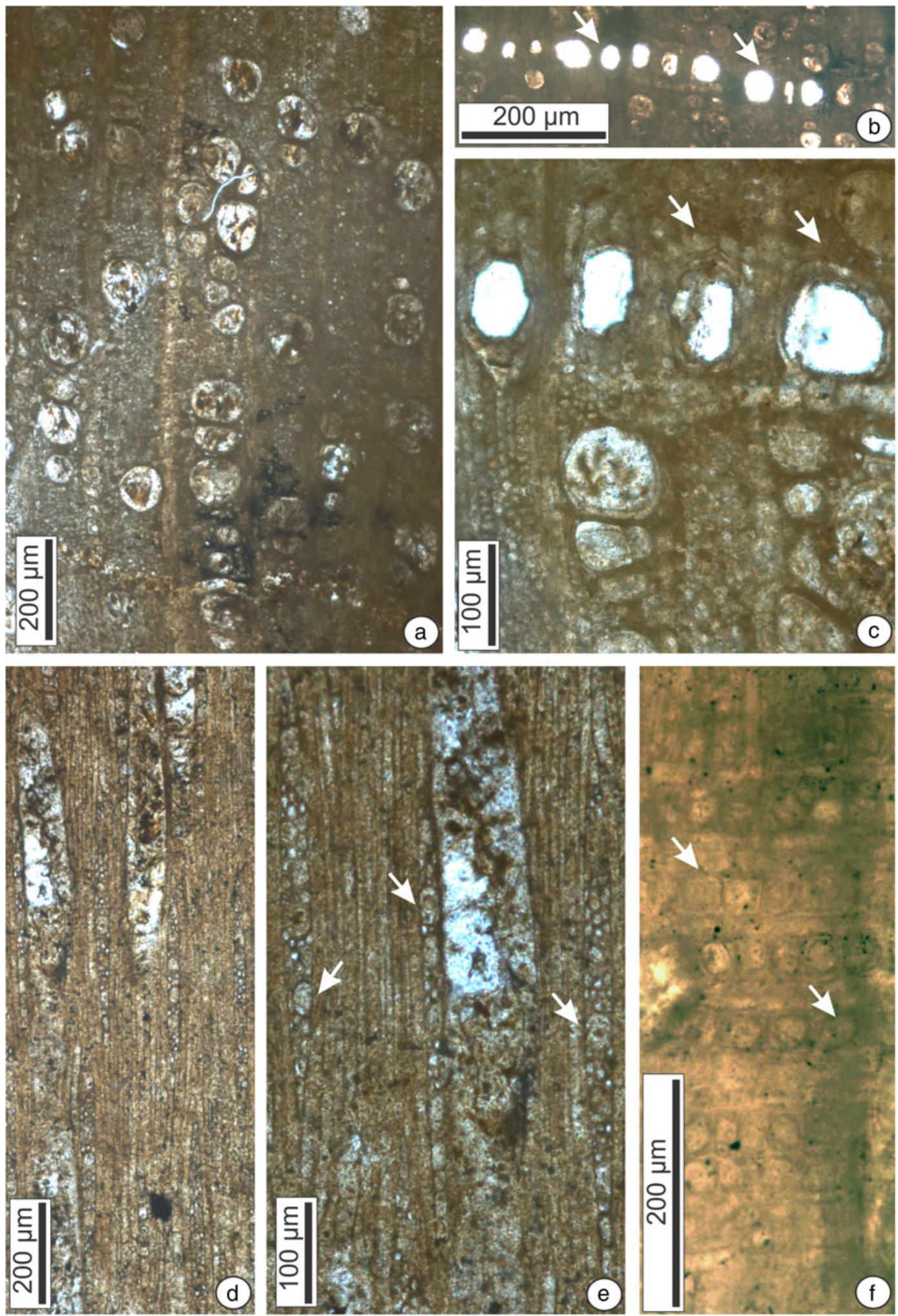

Figure 4. Hopenium pondicherriense Awasthi (a) T.S. of the fossil showing solitary as well as grouping of vessels, (b) T.S. showing tangentially arranged gum canals (marked by arrows), (c) T.S. showing gum canals enclosed in parenchyma bands (marked by arrows), (d), (e) T.L.S. of the fossil showing 3-4 seriate rays with crystalliferous upright cells interspersed among the procumbent cells (marked by arrows), and (f) R.L.S. of the fossil showing heterogeneous ray tissues with crystalliferous upright cells (marked by arrows). 
high and 22-100 $\mu \mathrm{m}$ wide, sheath cells present on the flanks of multiseriate rays (figure 3d); diameter of procumbent and upright cells 13-15 $\mu \mathrm{m}$ and $20-45 \mu \mathrm{m}$, respectively. Fibres thick walled, non-septate, semi-libriform, 36-48 $\mu \mathrm{m}$ wide. Gum canals vertical, normal, solitary or in tangential groups of 2-4, smaller than vessels, t.d. $65-80 \mu \mathrm{m}$ and r.d. 35-65 $\mu \mathrm{m}$ (figure $3 \mathrm{~b}$ ).

Figured specimen: Specimen no. BSIP 40065.

Horizon: Shumar Formation.

Locality: Near Habur Village, Jaisalmer District, Rajasthan.

Age: ?Plio-Pleistocene.

Affinities: The characteristic features of the fossil such as almost solitary medium to large vessels, vasicentric tracheids, broad rays with uniseriate tails of upright cells, sheath cells, non-septate fibres and diffuse gum canals indicate its close proximity to the dipterocarpaceous woods (Pearson and Brown 1932; Metcalfe and Chalk 1950; Kribs 1959; Miles 1978; Ilic 1991). The genera of the family have been categorized into two groups on the basis of the arrangement of gum canals (Ghosh 1958); (i) gum canals always in concentric rings (e.g., Shorea Roxb., Doona Thwaites, Hopea Roxb., Parashorea Kurz., Pantacme A. DC., Balanocarpus Bedd. and Dryobalanops C.F. Gaertn.) and (ii) gum canals diffuse, solitary and in short tangential rows (e.g., Anisoptera Korth., Dipterocarpus Gaert f., Vatica L., Vateria L. and Cotylelobium Pierre). The present fossil in possessing diffuse gum canals falls into the second category. Among the genera of this category, the fossil best resembles to the Dipterocarpus particularly with D. indicus Bedd. (BSIP wood slide no. 308) and D. lowii Hook. f. (BSIP wood slide no. 2106). However, the former can be separated from the fossil by having greater frequency of gum canals.

Den Berger (1927) instituted the organ genus Dipterocarpoxylon Holden emend. Den Berger for the fossil woods resembling to Dipterocarpus. So far, a number of foosil woods have been described from various Tertiary exposures (Prakash 1973; Awasthi 1974, 1980; Mehrotra et al. 2006). Prasad and Khare (1994) have described their fossil wood directly under the modern genus Dipterocaprus. The present fossil wood was compared with the known fossil species and found similar to Dipterocarparoxylon jammuense (Guleria et al. 2002) described from the upper Tertiary sediments of Jammu region. This species has also been recorded from the Siwalik sediments of Dehradun, Uttaranchal (Guleria et al. 2005). Since our fossil wood is identical to D. jammuense, it has been placed under the same species.
The genus Dipterocarpus Gaertn. f. includes about 69 species and is mainly confined to the Indo-Malaysian region with maximum development in Borneo, Malaysian Peninsula and Sumatra (Mabberley 1997). The genus ranges in its distribution from India in the west to Philippines in the east. In India it is found in Assam, Andamans and Western Ghats (Ghosh 1958). Dipterocarpus lowii Hook. f., the modern counterpart of the fossil is mainly found in the Malaysian region.

Genus: Hopenium Awasthi (1980)

Hopenium pondicherriense Awasthi (1980)

Description: Wood diffuse porous. Growth rings indistinct. Vessels small to medium, rarely very small, solitary to radial multiples of $2-5$ (mostly 2-3) or forming clusters (figure 4a), circular to oval in shape, evenly distributed, t.d. $42-107 \mu \mathrm{m}$, r.d. 59-127 $\mu \mathrm{m}$, heavily tylosed (figure 4a, c); vessel elements 140-550 $\mu \mathrm{m}$ long; perforations simple; intervessel pits poorly preserved, alternate. Vasicentric tracheids present, not easily recognizable from parenchyma. Axial parenchyma paratracheal and apotracheal, paratracheal parenchyma intermingled with vasicentric tracheids, forming thin sheath around the vessels or vessel groups (figure 4c), sometimes appearing aliform or confluent when vessels are closely spaced; apotracheal parenchyma in the form of tangential bands enclosing gum canals (figure 4c); cells thin walled. Rays 1-4 (mostly 3-4) seriate (figure 4d), 10-50 cells or 595-800 $\mu \mathrm{m}$ high and $20-28 \mu \mathrm{m}$ wide; ray tissue heterogeneous (figure 4f); rays heterocellular consisting of 1-5 marginal rows of upright to square cells and procumbent cells through the median portion; crystalliferous upright cells interspersed among the procumbent cells (figure 4e), diameter of procumbent cells $12-18 \mu \mathrm{m}$ and upright cells 28-39 $\mu \mathrm{m}$. Fibres thick walled, 16-28 $\mu \mathrm{m}$ wide, non-septate. Gum canals normal, vertical, aligned in tangential rows forming concentric rings (figure 4b), circular to oval, 93-124 $\mu \mathrm{m}$ in diameter.

Figured specimen: Specimen no. BSIP 40066.

Horizon: Bhumbli Conglomerate.

Locality: Lakhanka-Mithi-Viri (east coast of

Bhavnagar), Bhavnagar District, Gujarat. Age: Miocene.

Affinities: The characteristic features of the fossil such as small to medium tylosed vessels froming clusters, vasicentric tracheids, concentric rings of vertical gum canals, heterocellular rays, crystalliferous upright to square cells interspersed among procumbent cells in the median portion indicate its affinity to the family Dipterocarpaceae. The categorization of the genera of Dipterocarpaceae on the 
basis of gum canals has been discussed in the earlier pages and since the present fossil possesses gum canals in concentric rings, it falls in the Ist category. Among the genera of Ist category, the fossil shows best resemblance to the genus Hopea Roxb. (including a Balanocarpus species, i.e., B. heimii King). However, Balanocarpus heimii also differs from the present fossil wood in having storied rays. A detailed comparison of the fossil was made with a large number of woods of the modern species of Hopea from their thin sections as well as published anatomical descriptions and photographs and the fossil was found to have resemblance with Hopea helferi Brandis and H. glabra Wight and Arn.

A number of fossil woods of Hopea described from various Tertiary sediments of India under the organ genus Hopenium (Awasthi 1980) are: Hopenium pondicherriense from the Cuddalore Series of south India and from the Siwalik sediments of Kalagarh (Awasthi 1980; Prasad 1993), $H$. neyveliensis from the Neyveli Lignite Mine (Awasthi 1984), H. kalagarhensis and H. prenutansoides from the Siwalik beds of Kalagarh (Prasad and Prakash 1988), H. payangadiensis from the Neogene sediments of Payangadi, Cannanore district, Kerala (Awasthi and Srivastava 1990) and Hopenium sp. cf. Hopea odorata (Prakash et al. 1994). Among these, the present wood is identical to Hopenium pondicherriense (Awasthi 1980). $H$. neyveliensis could be differentiated by having bigger gum canals and closely spaced parenchyma bands, whereas in $H$. prenutansoides, gum canals are smaller than the present fossil and parenchyma bands are broader. H. kalagarhensis and $H$. payangadiensis also differ by having bigger gum canals, whereas Hopenium sp. cf. Hopea odorata can be distinguished by having mostly $4-5$ seriate rays.

Hopea glabra is a medium-sized tree found only in south India in the evergreen forest of South Kanara, Travancore and Tinnevelly up to $1200 \mathrm{~m}$ altitude and often grows along the river banks, whereas $H$. helferi is a large tree found in semievergreen and evergreen forests of Cambodia, India (Andaman), Malaysia, Myanmar and Thailand.

Genus: Shoreoxylon Den Berger (1923)

Shoreoxylon burmense Prakash (1965a, b)

Description: Wood diffuse-porous. Growth rings not seen. Vessels medium to large, mostly solitary, rarely in pairs (figure 5a, b), t.d. 130-240 $\mu \mathrm{m}$, r.d. 224-350 $\mu \mathrm{m}$, evenly distributed, 5-6 per $\mathrm{mm}^{2}$, round to oval in shape; tyloses or gummy deposits present; vessel elements 400-650 $\mu \mathrm{m}$ long with truncate ends; perforations simple; intervessel pits small, alternate, bordered with liner to lenticular apertures (figure 5f). Vasicentric tracheids intermingled with paratracheal parenchyma. Axial parenchyma paratracheal and apotracheal, paratracheal parenchyma vasicentric, $4-5$ celled sheath around the vessels, rarely short extensions present (figure 5b); apotracheal parenchyma diffuse, occurring as solitary cells or in tangential bands associated with the gum canals (figure $5 \mathrm{a}$ ); cells thin walled. Rays 1-4 (mostly 2-3) seriate (figure 5c, d), homocellular or weakly heterocellular, ray tissue weakly heterogeneous (figure 5e), rays 4-37 cells or $95-760 \mu \mathrm{m}$ high and $12-75 \mu \mathrm{m}$ wide, made up of mostly procumbent cells and sometimes upright cells present at the margins (figure 5e); diameter of procumbent cells 20-32 $\mu \mathrm{m}$. Fibres libriform, thick walled, non-septate and polygonal as seen in cross section. Gum canals vertical, arranged in tangential rows, embedded in parenchymatous tissue, round to oval, $45-150 \mu \mathrm{m}$ in diameter (figure $5 \mathrm{a}$ ).

Figured specimen: Specimen no. BSIP 40067.

Horizon: Kand Formation.

Locality: Ratanpurni river bed, Ratanpor, Bharuch

District, Gujarat.

Age: Lower Miocene.

Affinities: The important anatomical features of the fossil are: medium to large vessels, vasicentric tracheids, vasicentric and diffuse apotracheal parenchyma, mostly 2-3 seriate rays, weakly heterogeneous tissue, non-septate fibres and tangentially rowed gum canals embedded in parenchyma bands. All these anatomical features of the wood show its close affinity with the modern woods of the Dipterocarpaceae, particularly with the group of first category proposed by Ghosh (1958) who categorized the woods of the family into two groups on the basis of the arrangement of gum canals. In the present fossil, gum canals are tangentially arranged and hence, fall into the first group of Ghosh. Among the genera of this group, the fossil shows similarity with Shorea. For further identification the fossil was compared with the published literature (Ghosh 1958; Hayashi et al. 1973) and available thin sections of the modern woods of Shorea Roxb. and found similar to Shorea ovalis (Korth.) Bl. (BSIP wood slide no. 2129).

About 30 fossil wood species of Shorea are known from India and abroad under the organ genus Shoreoxylon (Den Berger 1923; Prakash 1973; Awasthi 1974; Prasad and Prakash 1988; Bera and Banerjee 2001). Among these the following nine species were described from the Neogene of India: Shoreoxylon arcotense (Awasthi 1974), S. cuddalorense (Gurusamy and Kumarasamy 2007) and S. indicum (Awasthi 1974) from south India, S. robustoides (Roy and Ghosh 1981) from West Bengal, S. burmense (Prakash et al. 1994), S. deomaliense (Prakash and Awasthi 1971), 

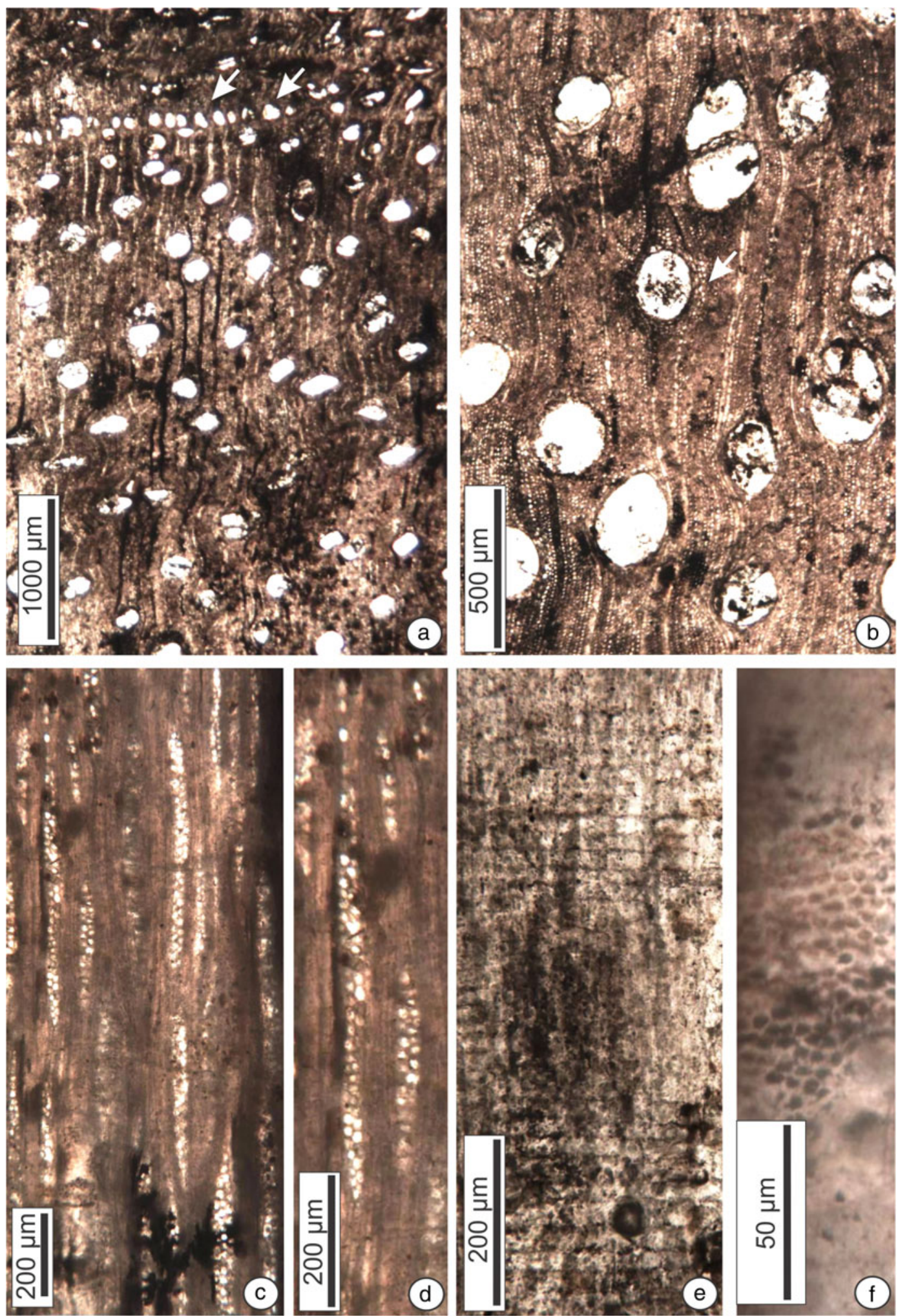

Figure 5. Shoreoxylon burmense Prakash (a) T.S. of the fossil showing predominantly solitary vessels and tangentially arranged gum canals (marked by arrows), (b) T.S. showing paratracheal parenchyma around the vessels (marked by arrow), (c), (d) T.L.S. of the fossil showing 2-3 seriate rays, (e) R.L.S. showing weakly heterogeneous ray tissue, and (f) R.L.S. showing alternate intervessel pits. 
S. tipamense (Prakash and Awasthi 1970) from northeast India and $S$. siwalicus (Prasad and Prakash 1988) from Himachal Pradesh. After comparison, the fossil was found to resemble to Shoreoxylon burmense, reported from the Tertiary of Myanmar (Burma) and northeast India (Prakash 1965a, b; Prakash et al. 1994). The anatomical characters of the $S$. burmense are very similar to the present fossil except that the rays are slightly broader ( $4-5$ seriate) in it. Considering it a minor variation, the present fossil has been assigned the same specific epithet.

Shorea is a genus of about 196 species of mainly rainforest trees and $S$. ovalis, the modern counterpart of the fossil, is a Malaysian species.

\section{Discussion}

The movement of the Indian plate from south to north vis-à-vis climate change has always been a matter of concern for the palaeobotanists. The Indian plate separated from the other Gondwanaland continents around $90 \mathrm{Ma}$ and further moved from southern to northern hemisphere and collided with the Eurasian plate around the mid Cenozoic (Beck et al. 1995; Storey et al. 1995). This collision caused the uplift of the Himalaya and Tibetan plateau ( $\sim 50 \mathrm{Ma})$ which constitutes a significant forcing factor on the intensity of the Asian monsoon (Kutzbach et al. 1989; Molnar et al. 1993; An et al. 2001; Zachos et al. 2001; Spicer et al. 2003). The northward movement from mid southern latitudes to the equatorial zone is evidenced by the tropical climate and thick vegetation cover, during the Cenozoic time, on the entire Indian subcontinent, including western India (Prasad et al. 2009) and is also envisaged by the presence of thick lignite deposits at the margins of western India. This indicates existence of well established equatorial rainforests, which are now restricted to the Western Ghats (Prasad et al. 2009), in the Indian subcontinent (including westernmost parts) during the early Palaeogene time. The best example of this is the presence of Dipterocarpaceae, usually a dominant component of the humid tropical and subtropical flora of the Indo-Malayan region with mean annual precipitation of $\sim 1438$ $4172 \mathrm{~mm}$, during the early Palaeogene time in western India. Here we have reported more dipterocarpaceous remains from the same region but from the Neogene sediments indicating the extension of the family into the Neogene time as well. Contrary to this, not a single taxon of Dipterocarpaceae is growing in the region today. Apart from western India, the family also suffered a gradual decline both numerically and phytogeographically (Awasthi 1994) on the entire Indian subcontinent. The widespread distribution of the Dipterocarpaceae in the Indian subcontinent in deep time clearly indicates that the uniform tropical climate with higher amount of annual rainfall existed throughout the Indian peninsula during the early Eocene Pliocene (Awasthi 1994; Prasad et al. 2009; Shukla et al. 2012). The distribution of Dipterocarpaceae in the Indian subcontinent today is restricted to the evergreen forest of Assam, Western Ghats and Andamans (Ghosh 1958; Santapau and Henry 1973; Prasad et al. 2009).

The change in the vegetation type is directly related to the change in the climatic conditions. The uniform tropical conditions during the Cenozoic prevailing on the entire Indian subcontinent started deteriorating due to the initiation, evolution and strengthening of the monsoon during the Neogene. The continuous uplift of the Tibetan plateau, following the India-Asia collision, is considered as the primary cause of monsoon initiation and intensification (Ruddiman and Kutzbach 1989; An et al. 2001; Zheng et al. 2004). It was speculated that the monsoon intensified between 9 and $6 \mathrm{Ma}$, when the Tibetan plateau attained sufficient height to act as a heat source and to block northward air fluxes (Molnar et al. 1993). The winds rich in moisture are drawn towards Himalayas which act like a high wall, thus, forcing them to rise. With the gain in altitude of the clouds, the temperature drops and rains occur. Results of atmospheric circulation modelling suggest that the Himalayas acted as an orographic barrier (Boos and Kuang 2010), pushing the onset of monsoon intensification sometime into the midMiocene (Ramstein et al. 1997). The paleobotanical records of western India indeed agree with this view.

The age of initiation of the east and south Asian monsoons is controversial, but a variety of environmental factors suggest that the east Asian monsoon was established by the beginning of the Neogene ( $24 \mathrm{Ma})$ (Clift et al. 2008). Recently, Srivastava et al. (2012) recorded a strong monsoon signal in the Late Oligocene (28-23 Ma) for the southeast Asia. There is a general consensus for a dramatic change in the monsoon system about 6-8 Ma ago, as marked by faunal evidences for increased upwelling in the Arabian Sea (Kroon et al. 1991), an increase in clay mineral fraction recovered from the Bengal fan (Derry and FranceLanord 1996) and ecological shift seen in northern Pakistan (Quade et al. 1989).

Zachos et al. (2001) on the basis of $\delta^{18} \mathrm{O}$ isotopes showed episodes of global warming and cooling (Zachos et al. 2001). The most pronounced warming trend, as expressed by a $1.5 \%$ decrease in $\delta^{18} \mathrm{O}$, occurred early in the Cenozoic from Paleocene (59 Ma) to Early Eocene (52 Ma) and 
peaked with the Early Eocene Climatic Opti$\operatorname{mum}($ EECO; $52 \mathrm{Ma})$. This warming was followed by a $17-\mathrm{My}$-long trend towards cooler conditions and rapid expansion of Antartica continental icesheets in the earliest Oligocene persisted until the later part of the Oligocene (26-27 Ma). A warming trend, late Middle Miocene Climatic Optimum (17 to $15 \mathrm{Ma}$ ), reduced the extent of Antarctic ice till the Middle Miocene $(\sim 15 \mathrm{Ma})$. The Middle Miocene climatic optimum has also been proposed as a period of enhanced weathering, erosion and organic carbon burial (Wan et al. 2009). This warm peak was followed by a gradual cooling and reestablishment of a major ice-sheet on Antartica by $10 \mathrm{Ma}$. These warm phases are evidenced by the presence of typical wet tropical families like Dipterocarpaceae on the Indian subcontinent during both the Palaeogene and Neogene (Dutta et al. 2011a; Shukla et al. 2012). Similarly, by using eolian sediments from China and marine sediments from Indian and north Pacific Ocean, An et al. (2001) identified three stages in the evolution of Asian climates: (a) enhanced aridity in the Asian interior and onset of the India and east Asian monsoons ( 9-8 Ma), (b) continental intensification of the east Asian summer and winter monsoons, together with increased dust transport to the north Pacific Ocean ( 3.6-2.6 Ma) and (c) increased variability and possible weakening of the Indian and east Asian summer monsoons and continued strengthening of the east Asian winter monsoon since $\sim 2.6 \mathrm{Ma}$. The above facts support the argument that the stages in evolution of Asian monsoons are linked to phases of Himalaya-Tibetan plateau and Northern Hemisphere glaciations. The other possible influences on Late Miocene-Pliocene climates are change in ocean gateways (Haug and Tiedemann 1998), decrease in atmospheric $\mathrm{CO}_{2}$ concentration due to increased weathering or carbon burial (Raymo et al. 1988) and changes in land/ocean configuration (Ramstein et al. 1997).

All these factors are ultimately responsible for the establishment of drier climatic conditions in the westernmost part of the Indian subcontinent in the late Neogene (Prell et al. 1992; An et al. 2001) and extinction of the many tropical families, viz., Dipterocarpaceae from the region. Stable isotope data on calcretes indicates initiation of a monsoonal climate in the Thar during the Neogene at around $0.8 \mathrm{Ma}$ (Deotare et al. 2004).

A thorough review of the climatic shift during the Neogene which caused deterioration of ubiquitous tropical vegetation existed over entire Indian subcontinent led to a conclusion that the emergence as well as extinction of Dipterocarpaceae is directly related to the change in the climatic conditions. The family Dipterocarpaceae was widespread on the entire Indian subcontinent from the Early Eocene onwards up to the PlioPleistocene (Lakhanpal et al. 1984; Dutta et al. 2009, 2011a, b; Shukla et al. 2012) (figure 1), along with the other known elements (Guleria 1983, 1984a, b, 1990, 1991, 1992a, 1994, 1996; Lakhanpal et al. 1984; Guleria et al. 2009; Shukla et al. 2012). This further indicates a more or less warm and humid climate supporting the luxuriant vegetation during the period as all the nearest living relatives (NLRs) of the present and earlier described fossils are distributed in the evergreen to deciduous forests of the Indo-Malayan region (Lakhanpal et al. 1984; Shukla et al. 2012).

Dipterocarpaceae is an important family of tropical rainforests and to explain its origin two hypotheses exist; the first one advocates for the Malaysian origin, arguing that two-third of the total dipterocarp species occur there today and the region is also quite rich in its fossil records (Lakhanpal 1974; Sasaki 2006; Shukla et al. 2012). According to this, the family migrated from southeast Asia to India during the Neogene when the land connections were established between the two landmasses (Lakhanpal 1970; Awasthi 1994). The other hypothesis supports the Gondwanic origin based on phylogenetic studies comparing Dipterocarpaceae with the Sarcolaenaceae, a tree family endemic to Madagascar. These two also share a common ectomicorrhizal ancestor (Ducousso et al. 2004; Dutta et al. 2009; Rust et al. 2010; Beimforde et al. 2011). Recently, a few microfossils and chemical analysis of the resin (Dutta et al. 2009, 2011a, b) from the Eocene of western India supported the 'Out of India' hypothesis for the family. According to this hypothesis, the dispersal of the family into southeast Asia took place only when it came on rafting with the Indian plate from south to north. As far as the megafossil records of the family are concerned, its fossils are found in India only from the Early Miocene onwards (Guleria 1992b; Shukla et al. 2012), despite the fact that we have well established megafossil records from the Late Cretaceous to Palaeogene age from the Indian subcontinent (Mehrotra 2003). From the Palaeogene of India, the only fossil wood resembling Dipterocarpaceae was reported by Rust et al. (2010). The wood needs re-investigation as it lacks many important features of the family Dipterocarpaceae. The fossil wood shows very low and thin rays (Rust et al. 2010; figure $\mathrm{S} 3 \mathrm{E}$ ); such rays are not found in this family. Moreover, the authors ignored the presence of hyaline cells among the fibres (Rust et al 2010; figure S3F) which look like the oil cells, characteristic feature of the family Lauraceae. In this family, thin and low rays are commonly found (Ghosh 1958; Kribs 1959; Hayashi et al. 1973; Miles 1978; Ilic 1991). Further, the oil cells might have been misinterpreted by the 
authors as gum canals in the cross-section of the fossil wood (Rust et al. 2010; figure S3A). Further discovery of reliable megafossil evidences from the early Palaeogene sediments would strengthen the 'Out of India' hypothesis.

\section{Acknowledgements}

The authors are thankful to Dr. N C Mehrotra, Director, Birbal Sahni Institute of Palaeobotany, Lucknow for providing constant encouragement, infrastructure facilities and permission to publish this work. Thanks are also due to the authorities of the Forest Research Institute for their support at the time of consultation. They express their gratitude to Prof. A Sarkar and the anonymous reviewer for their constructive suggestions to improve the manuscript.

\section{References}

Acharya M 2000 Early Eocene palynofossils from subsurface of mannargudi area, Tamil Nadu, India; Geophytology 28 19-30.

Aiba S I and Kitayama K 1999 Structure, composition and species diversity in an altitude-substrate matrix of rain forest tree communities on Mount Kinabalu, Borneo; Plant Ecol. 140 139-157.

An Z S, Kutzbach J E, Prell W L and Porter S C 2001 Evolution of Asian monsoons and phased uplift of the Himalaya-Tibetan plateau since Late Miocene times; Nature 411 62-66.

Antal J S and Prasad M 1996 Dipterocarpaceous fossil leaves from Ghish River section in Himalayan foothills near Oodlabari, Darjeeling District, West Bengal; Palaeobotanist 43 73-77.

Ashton P S 1982 Dipterocarpaceae; In: Flora Malesiana Series 1 (ed.) Van Steenis C G G J (Hague: MartinusNijhoff Publications) Spermatophyta 9 237-552.

Ashton P S 1988 Dipterocarp biology as a window to the understanding of tropical forest structure; Ann. Rev. Ecol. Syst. 19 347-370.

Ashton P S 2003 Dipterocarpaceae; In: The families and genera of vascular plants $V$ : Flowering plant-DicotyledonsMalvales, Capparales and Non-betalain Caryophyllales (eds) Kubitzki K and Bayer C (Berlin, Heidelberg, New York: Springer), pp. 182-197.

Awasthi N 1974 Occurrence of some dipterocarpaceous woods from the Cuddalore Series of south India; Palaeobotanist 21 339-351.

Awasthi N 1980 Two new dipterocarpaceous woods from the Cuddalore Series near Pondicherry; Palaeobotanist 26 248-256.

Awasthi N 1984 Studies on some carbonized woods from the Neyveli Lignite deposits, India; Geophytology 14 82-95.

Awasthi N 1994 Dipterocarpus in the Indian subcontinent: Past, present and future; In: Proceedings of fifth round-table conference on Dipterocarpus, Chiang Mai (Thailand), pp. 138-156.

Awasthi N and Mehrotra R C 1993 Further contribution to the Neogene flora of northeast India and significance of the occurrence of African element; Geophytology $\mathbf{2 3}$ 81-92.

Awasthi N and Srivastava R 1990 Some new carbonized woods from the Neogene of Kerala coast and their bearing on Palaeoclimate; Palaeobotanist 38 285-292.
Bancroft H 1935 The taxonomic history and geographical distribution of the Monotoideae; Am. J. Bot. 22 $505-519$.

Beck R A, Burbank D W, Sercombe W J, Riley G W, Barndt J K, Berry J R, Afzal J, Khan A M, Jurgen H, Metje J, Cheema A, Shaflque N A, Lawrence R D and Khan A 1995 Stratigraphic evidence for an early collision between northwest India and Asia; Nature 373 55-58.

Beimforde C, Schäfer N, Dörfelt H, Nascimbene P C, Singh H, Heinrichs J, Reitner J, Rana R S and Schmidt A R 2011 Ectomycorrhizas from a Lower Eocene angiosperm forest; New Phytol. 192 988-996.

Bera S and Banerjee M 2001 Petrified wood remains from Neogene sediments of Bengal Basin, India, with remarks on palaeoecology; Palaeontographica B 260 167-199.

Biswas S K 1965 A new claissification of Tertiary rocks of Kutch, western India; Bull. Geol. Min. Metall. Soc. India 35 1-6.

Biswas S K 1971 Note on the geology of Kutch; Quat. J. Geol. Min. Metall. Soc. India 43 223-235.

Biswas S K and Deshpande S V 1970 Geological and tectonic maps of Kutch; Bull. Oil Nat. Gas Comm. 7 115-116.

Boos W R and Kuang Z 2010 Dominant control of the south Asian monsoon by orographic insulation versus plateau heating; Nature 463 218-222.

Clift P B, Hodges K V, Heslop D, Hannigan R, Long H V and Calves 2008 Correlation of Himalayan exhumation rates and Asian monsoon intensity; Nature Geosci. 1 875-880.

Dasgupta S K 1975 A revision of Mesozoic-Tertiary stratigraphy of the Jaisalmer Basin, Rajasthan; Indian J. Earth Sci. 2 77-99.

Den Berger L G 1923 Fossiele houtsoorten uit het Tertiair van Zuid-Sumarta; Ver. Geol. Mijnb. Genoot. Ned. (Geol. Ser.) 7 143-148.

Den Berger L G 1927 Unterscheidungsmerkmale von rezenten und fossilen Dipterocarpaceen gattungen; Bull. Jard. Bot. Buitenz 3 495-498.

Deotare B C, Kajale M D, Rajaguru S N and Basavaiah N 2004 Late Quaternary geomorphology, palynology and magnetic susceptibility of playas in western margin of the Indian Thar Desert; J. Ind. Geophys. Union 8 15-25.

Derry L A and France-Lanord C 1996 Neogene Himalayan weathering history and river ${ }^{87} \mathrm{Sr} /{ }^{86} \mathrm{Sr}$ : Impact on the marine Sr record; Earth Planet. Sci. Lett. 142 59-74.

Ducousso M, Bena G, Bourgeois C, Buyck B, Eyssartier G, Vincelette M, Rabevohitra R, Randrihasipara L, Dreyfus B and Prin Y 2004 The last common ancestor of Sarcolaenaceae and Asian dipterocarp trees was ectomycorrhizal before the India-Madagascar separation, about 88 million years ago; Mol. Ecol. 13 231-236.

Dutta S, Mallick M, Bertram N, Greenwood P F and Mathews R P 2009 Terpenoid composition and class of Tertiary resins from India; Int. J. Coal Geol. 80 44-50.

Dutta S, Tripathi S M, Mallik M, Mathews R P, Greenwood P F, Malagalapalli R R and Summons E 2011a Eocene out-of-India dispersal of Asian dipterocarps; Rev. Palaeobot. Palynol. 116 63-68.

Dutta S, Mathews R P, Singh B D, Tripathi S M, Singh A, Saraswati P K, Banerjee S, Ulrich M 2011b Petrology, palynology and organic geochemistry of Eocene lignite of Matanomadh, Kutch Basin, western India: Implications to depositional environment and hydrocarbon source potential; Internat. J. Coal Geol. 85 91-102.

Fedden F 1884 Geology of Kathiawar peninsula in Gujarat; Geol. Surv. India Memoir 21 78-125.

Ghosh S S 1958 Family Dipterocarpaceae; In: Indian Woods (Delhi: The Manager of Publications), pp. 98-107.

Guleria J S 1983 Some fossil woods from the Tertiary of Kachchh, western India; Palaeobotanist 31 109-128. 
Guleria J S 1984a Leguminous woods from the Tertiary of District Kachchh, Gujarat, western India; Palaeobotanist 31 238-254.

Guleria J S 1984b Occurrence of anacardiaceous woods in the Tertiary of western India; Palaeobotanist 32 35-43.

Guleria J S 1990 Fossil dicotyledonous woods from Bikaner, Rajasthan, India; Geophytology 19 182-188.

Guleria J S 1991 On the occurrence of carbonized woods resembling Terminalia and Sonneratia in Palaeogene deposits of Gujarat, western India; Palaeobotanist 39 1-8.

Guleria J S 1992a A semi-ring porous fossil wood of Ziziphus from the Late Tertiary of Rajasthan; Palaeobotanist 39 303-308.

Guleria J S 1992b Neogene vegetation of peninsular India; Palaeobotanist 40 285-311.

Guleria J S 1994 Fossil leaf of Terminalia from the Rajpardi Lignite mine, district Bharuch, Gujarat, India; Geophytology 24 55-58.

Guleria J S 1996 Occurrence of Dipterocarpus in the Mar Formation of Bikaner, Rajasthan, western India; Palaeobotanist 43 49-53.

Guleria J S and Shukla A 2011 Gymnospermous woods from Late Cenozoic sediments of Rajasthan western India; Palaeobotanist 60 355-362.

Guleria J S and Srivastava Rashmi 2001 Fossil dicotyledonous woods from the Deccan Intertrappean beds of Kachchh, Gujarat, western India; Palaeontographica 257B 17-33.

Guleria J S, Gupta S S and Srivastava R 2002 Fossil woods from the Upper Tertiary sediments of Jammu region (Jammu \& Kashmir), north-west India and their significance; Palaeobotanist 50 225-246.

Guleria J S, Srivastava R, Nanda A C and Sehgal R K 2005 Two fossil woods from the Siwalik subgroup of northwestern Himalaya; J. Geol. Soc. India 66 609-616.

Guleria J S, Sahni A, Shukla A and Singh H 2009 A Teredolites-infested fossil wood from the Lower Eocene sediments of the Vastan Lignite Mine of Gujarat, western India; Palaeobotanist 58 93-99.

Gurusamy V and Kumarasamy D 2007 A new species of Shoreoxylon from the Cuddalore series, Tamil Nadu, India; Plant Archives 7 165-167.

Haug G H and Tiedemann R 1998 Effect of the formation of the Isthmus of Panama on Atlantic Ocean thermohaline circulation; Nature 393 673-676.

Hayashi S, Kishima T, Lau L C, Wong T M and Menon P K B 1973 Monographic Atlas of Southeast Asian Timbres (Kyoto: Wood Research Institute).

Ilic J 1991 CSIRO Atlas of Hardwoods (New York: Springer).

International Association of Wood Anatomists 1989 IAWA list of microscopic features for Hardwood identification; IAWA n.s. 10 219-332.

Khan M A and Bera S 2010 Record of fossil fruit wing of Shorea Roxb. from the Neogene of Arunachal Pradesh; Curr. Sci. 98 1573-1574.

Kribs D A 1959 Commercial Foreign Woods on the American Market (Pennsylvania: The Pennsylvania State University), 203p.

Kroon D, Steens T and Troelstra S R 1991 Onset of monsoonal related upwelling in the western Arabian Sea as revealed by planktonic foraminifers; Proc. ODP Sci. Res. $117257-263$.

Kutzbach J E, Guetter P J, Ruddiman W F and Prell W L 1989 Sensitivity of climate to late Cenozoic uplift in southern Asia and the American West: Numerical experiments; J. Geophys. Res. 94 18,393-18,407.

Lakhanpal R N 1970 Tertiary floras of India and their bearing on the historical geology of the region; Taxon 19 675-694.

Lakhanpal R N 1974 Geological history of the Dipterocarpaceae; In: Symposium on origin and phytogegraphy of angiosperms (ed.) Lakhanpal R N (Lucknow: Birbal Sahni Institute of Palaeobotany), pp. 30-39.

Lakhanpal R N and Guleria J S 1987 Fossil leaves of Dipterocarpus from the Lower Siwalik beds near Jawalamukhi, Himachal Pradesh; Palaeobotanist 35 258-262.

Lakhanpal R N, Guleria J S and Awasthi N 1984 The fossil floras of Kachchh III Tertiary megafossils; Palaeobotanist 33 228-319.

Lemoigne Y 1978 Flores tertiaires de la haute vallee de l'Omo (Ethiopie); Palaeontographica Abt. B 165 89-157.

Mabberley D J 1997 The Plant Book II. A Portable Dictionary of Vascular Plants (Cambridge: Cambridge University Press).

Maguire B P C and Ashton P S 1977 Pakaramoideae, Dipterocarpaceae of the western hemisphere II. Systematic, geographic, and phyletic considerations; Taxon $\mathbf{2 6}$ 359-368.

Maury-Lechon G and Curtet L 1998 Biogeography and evolutionary systematics of Dipterocarpaceae; In: A review of Dipterocarps: Taxonomy, ecology and silviculture (eds) Appanah S and Turnbull J M (Bogor: Center for International Forestry Research), pp. 5-44.

Mehrotra R C 2003 Status of plant megafossils during the Early Paleogene in India; In: Causes and consequenses of globally warm climates in the Early Paleogene (eds) Wing S L, Gingerich P D, Schmitz B and Thomas E (Boulder, Colorado: Geological Society of America Special Paper), 423p.

Mehrotra R C and Bhattacharyya A 2002 Wood of Dipterocarpus from a new locality of the Champanagar Formation of Tripura, India; Palaeobotanist 51 123-127.

Mehrotra R C, Bhattacharyya A and Shah S K 2006 Petrified Neogene woods of Tripura; Palaeobotanist 55 67-76.

Merh S S 1995 Geology of Gujarat; Geological Society of India, Bangalore.

Metcalfe C R and Chalk L 1950 Anatomy of the Dicotyledons, 1 \& 2 (Oxford: Clarendon Press).

Miles A 1978 Photomicrographs of World Woods (London: Department of the Environment Building Research Establishment).

Molnar P, England P and Martinrod J 1993 Mantle dynamics, uplift of the Tibetan Plateau, and the Indian monsoon; Rev. Geophys. 31 357-396.

Muller J 1981 Fossil pollen records of extant angiosperms; Bot. Rev. 47 1-142.

Narayanan K, Subramanyam M and Srinivasan S 1961 Geology of Jaisalmer; Oil \& Natural Gas Comm. Rep. (unpublished).

Navale G 1962 Some silicified dipterocarpaceous woods from Tertiary beds of the Cuddalore series near Pondicherry, India; Palaeobotanist 11 66-81.

Pandey D K, Yasuo Kondo, Jain R L, Tej Bahadur and Pradhan V R 2008 Microfossils and depositional environment of the Gaj Formation (Miocene) exposed near Bhatia District Jamanagar, Saurashtra; J. Palaeontol. Soc. India 53 131-145.

Pearson R S and Brown H P 1932 Commercial Timbers of India, 1 \& 2 (Calcutta: Government of India, Central Publication Branch).

Prakash U 1965a Fossil wood of Dipterocarpaceae from the Tertiary of Burma; Curr. Sci. 34 181-182.

Prakash U 1965b A survey of the fossil dicotyledonous woods from India and the far east; J. Paleontol. 39 815-827.

Prakash U 1973 Foosil woods from the Tertiary of Burma; Palaeobotanist 20 48-70.

Prakash U and Awasthi N 1970 Fossil woods from the Tertiary of eastern India I; Palaeobotanist 18 32-44.

Prakash U and Awasthi N 1971 Fossil woods from the tertiary of eastern India II; Palaeobotanist 18 219-225. 
Prakash U, Vaidyanathan L and Tripathi P P 1994 Plant remains from the Tipam sandstones of northeast India with remarks on the palaeoecology of the region during the Miocene; Palaeontographica Abt. B 231 113-146.

Prasad M 1990 Some more leaf-impressions from the lower Siwalik sediments of Koilabas, Nepal; Palaeobotanist 37 299-305.

Prasad M 1993 Siwalik (Middle Miocene) woods from the Kalagarh area in the Himalayan foot hills and their bearing on palaeoclimate and phytogeography; Rev. Palaeobot. Palynol. 76 49-82.

Prasad M 1994 Siwalik (Middle Miocene) leaf-impressions from the foot-hills of Himalayas, India; Ter. Res. 15 53-90.

Prasad M and Khare E G 1994 Occurrence of Dipterocarpus Gaert. f. in the Siwalik sediments of Hardwar, Uttar Pradesh, India; Biol. Mem. 20 51-54.

Prasad M and Prakash U 1988 Occurrence of Malayan dipterocarps in the Siwalik sediments of Uttar Pradesh; Geophytology 17 245-255.

Prasad V, Farooqui A, Tripathi S K M, Garg R and Thakur B 2009 Evidence of Late Palaeocene-Early Eocene equatorial rain forest refugia in southern Western Ghats, India; J. Biosci. 34 771-797.

Prell W L, Murray W D, Clemens C S and Anderson D M 1992 Evolution and variability of the Indian Ocean Summer Monsoon: Evidence from the western Arabian Sea drilling program. Synthesis of results from scientific drilling in the Indian Ocean; In: Synthesis of Results from Scientific Drilling in the Indian Ocean (eds) Duncan R A, Rea D K, Kidd B, Rad U Von and Weissel J K (Washington DC: Geophysical Monograph, American Geophysical Union), pp. 447-469.

Quade J, Cerling T E and Bowman J E 1989 Development of Asian monsoon revealed by marked ecological shift during the latest Miocene in northern Pakistan; Nature 342 $163-166$.

Ramanujam C G K 1956 Fossil woods of Dipterocarpaceae from the Tertiary of South Arcot district Madras; Palaeobotanist 4 45-56.

Ramstein G, Fluteau F, Besse J and Joussaume S 1997 Effect of orogeny, plate motion and land-sea distribution on Eurasian climate change over the past 30 million years; Nature 386 789-795.

Raymo M E, Ruddiman W F and Froelich P N 1988 Influence of late Cenozoic mountain building on ocean geochemical cycles; Geology 16 649-653.

Roy S K and Ghosh P K 1981 Shoreoxlon robustoides sp. nov., a new fossil wood of Dipterocarpaceae from the Tertiary of West Bengal, India; J. Indian Bot. Soc. 60 307-311.

Ruddiman W F and Kutzbach J E 1989 Forcing of late Cenozoic northern hemisphere climate by plateau uplift in southern Asia and the American west; J. Geophys. Res. 94 18,409-18,427.

Rugmai W, Grote P J, Chonglakmani C, Zetter R and Ferguson D K 2008 A Late Pleistocene palynoflora from the coastal area of Songkhla Lake, southern Thailand; Science Asia 34 137-145.

Rust J, Singh H, Rana R S, McCann T, Singh L, Anderson K, Sarkar N, Nascimbene P, Stebner F, Thomas J C, Solórzano M K, Williams C J, Engel M S, Sahni A and Grimaldi D 2010 Biogeographic and evolutionary implications of a diverse paleobiota in amber from the early Eocene of India; PNAS 107 18,360-18,365.
Santapau H and Henry A N 1973 A Dictionary of the Flowering Plants in India (New Delhi: CSIR).

Sasaki S 2006 Ecology and physiology of Dipterocarpaceae; In: Plantation Technology in Tropical Forest Science (eds) Suzuki K, Ishii K, Sakurai S and Sasaki S (Tokyo: Springer), pp. 3-22.

Schweitzer H 1958 Die Fossilen Dipterocarpaceen-Hölzer; Palaeontographica Abt. B 105 1-66.

Shi G and Li H 2010 A fossil fruit wing of Dipterocarpus from the middle Miocene of Fujian, China and its palaeoclimatic significance; Rev. Palaeobot. Palynol. 162 599-606.

Shukla A, Guleria J S and Mehrotra R C 2012 Fossil record of a Shorea Roxb. fruit wing from the Early Miocene sediments of Kachchh, Gujarat and its bearing on palaeoclimatic interpretation; J. Earth Syst. Sci. 121 195-201.

Singh N P 1982 Subsurface post-Eocene deposits of Jaisalmer Basin, Rajasthan: First National Seminar on Quaternary Environment, Recent Research; Geology 9 234-243.

Singh N P 2007 Cenozoic lithostratigraphy of the Jaisalmer Basin, Rajasthan; J. Palaeontol. Soc. India 52 129-154.

Songtham W, Ratanasthien B, Watanasak M, Mildenhall D C, Singharajwarapan S and Kandharosa W 2005 Tertiary basin evolution in northern Thailand: A palynological point of view; Nat. Hist. Bull. Siam. Soc. 53 17-32.

Spicer R A, Harris N B W, Widdowson M, Herman A B, Guo S, Valdes P J, Wolfe J A and Kelley S P 2003 Constant elevation of southern Tibet over the past 15 million years; Nature 421 622-624.

Srivastava P K 1963 Geology of Saurashtra (unpublished report of ONGC).

Srivastava G and Mehrotra R C 2010 Tertiary flora of northeast India vis-à-vis movement of the Indian plate; Geol. Soc. India Memoir 75 123-130.

Srivastava G, Spicer R A, Spicer T E V, Yang Jian, Kumar M, Mehrotra R C and Mehrotra N C 2012 Megaflora and palaeoclimate of a Late Oligocene tropical delta, Makum Coalfield, Assam: Evidence for the early development of the South Asia Monsoon; Palaeogeogr. Palaeoclimatol. Palaeoecol. 342-343 130-142.

Storey M, Mahoney J J, Saunders A D, Duncan R A, Kelley S P and Coffin M F 1995 Timing of hot spotrelated volcanism and the breakup of Madagascar and India; Science $\mathbf{2 6 7} 852-855$.

Tiwari R and Mehrotra R 2000 Fossil woods from the Tipam Group of Mizoram, India; Ter. Res. 20 85-94.

Wan S, Kurschner W M, Clift P D, Li A and Li T 2009 Extreme weathering/erosion during the Miocene Climatic Optimum: Evidence from sediment record in the South China Sea; Geophys. Res. Lett. 36 L19706, doi: 10.1029/2009GL040279.

Wang Y D, Zhang W, Zheng S L, Jintasakul P, Grote P J and Boonchai N 2006 Recent advances in the study of Mesozoic-Cenozoic petrified wood from Thailand; Progr. Nat. Sci. 16 501-506.

Zachos J, Pagani M, Sloan L, Thomas E and Billups K 2001 Trends, rythms, and aberrations in global climate $65 \mathrm{Ma}$ to present; Science 292 686-693.

Zheng H B, Powell C M, Rea D K, Wang J L and Wang P X 2004 Late Miocene and mid-Pliocene enhancement of the East Asian monsoon as viewed from the land and sea; Global Planet. Change 41 147-155. 